\title{
Analysis of Chinese M-commerce development strategy
}

\author{
Xinmin Zhang, Shengjun LI \\ department of Trade and economics Xingtai University Hebei Province, China \\ guozhang_44@163.com,85893372@qq.com
}

\begin{abstract}
M-commerce is an e-business system which is the organic combination of various mobile communications equipment and wireless network technology. At present, the awareness and trading habits of M-commerce need to be further developed and improved in China, and the technology, content, cost and safety issues of M-commerce need to be solved urgently. Therefore, we must establish and improve the $\mathrm{M}$-commerce legislation system as soon as possible, build safe and reliable M-commerce security system, and strengthen the cultivation of talents, to promote the research of M-commerce frontier theory.
\end{abstract}

Index Terms - M-commerce; E-business; Strategy

\section{Introduction}

E-business is the new emerging thing which is the result of the applications of electronic technology and Internet information processing technology in economic fields, and it is the result of the combination of the latest technology methods and social economic activities. Since entering the 21 st century, with the rapid development and popularity of the mobile communication technology, the electronic business activities via various kinds of mobile communication equipment has emerged. This new form of electronic business develops rapidly which obviously differs from traditional electronic business and then the mobile electronic commerce formed.

\section{The connotation of mobile electronic business}

M-commerce is the branch of E-business. It is the derivative of E-business and it is the electronic business system which consists of mobile communication equipment such as the mobile phone, PHA etc. and the wireless Internet technology. Owing to the combination of the Internet, mobile communication technology, short distance communication technology and other information processing technology, the $\mathrm{M}$-commerce emerges [1].

M-commerce enables people do all kinds of business activities anytime and anywhere. Thus, people can make deal and go shopping online or offline, do the online electronic payment and all kinds of deals, business, finance and other integrated service activities. At present, M-commerce mainly applies in the mobile phone finance, online deal, ticket booking online, shopping online, amusement, medical care etc.

The major feature of M-commerce is fast and convenient. With the popularity of wireless Internet and rapid development of mobile communication technology, the mobile signal nearly covers every corner of people's life. People can search rapidly with the help of variety of mobile terminals and connect to the mobile network, easy to carry out the M-commerce [2]. Mcommerce can satisfy the individual needs of the participants regardless of time and place, which is the major advantage of.
Meanwhile, M-commerce has relatively high security. People can do the electronic signature and identity authentication conveniently by using the advanced technology which is the combination of the mobile communication and Internet, so as to prevent the Internet fraud.

\section{The current status and problems of the Chinese M- commerce}

In the revolution wave of global information technology, the mobile communication has become the most active field in the telecommunications industry. The capacity of mobile communication has greatly and gradually improved. There is a great prospect of Chinese $\mathrm{M}$-commerce. The future is the era of M-commerce. But there are still many problems.

\section{1) The concept of M-commerce and dealing custom need to be cultivated and improved}

M-commerce is the new thing. Now the recognition degree about the M-commerce among the domestic users is relatively low [3]. The traditional business concept and the dealing custom can hardly change in a short time. The main factor of M-commerce development is to own and expand market continuously. The concept of M-commerce and consumption habits affects the expanse of M-commerce directly. So it is needed to strengthen the understanding and knowledge about M-commerce among the government, ventures as well as consumers and to conquer the constraints of consuming habits which have formed for a long time. Chinese M-commerce only stays in the stage of market cultivating and promoting and the concept of M-commerce and dealing custom is a gap that we must conquer [4].

\section{2 ) The problem of M-commerce technology, content and expenses is obvious}

M-commerce is based on the mobile communication technology. Therefore, it is bound to be limited by the development of communication technology. Compared to the wired communication, the cost of wireless communications is higher, the width of broadband is smaller, the lasting time is larger and the connection reliability is low and it can not be connected beyond the covered area. At the same time, the reaction speed of the mobile terminals is relatively slow and it has a limited screen size, memory as well as the total storage capacity is relatively limited. At present, the range of service of M-commerce is limited to news, advertisement, shopping and other several aspects. The content of service is not rich and lack attractions [5]. Also, the scanning service is not very smooth. For the purpose of the improvement of traditional 
electronic business, the service of M-commerce should be continuously enriched and improved. The consuming cost of mobile communications is relatively high. Many users want to take part in the mobile commerce activities. But they give up because of the high cost. The high cost affects the speed of Mcommerce development greatly.

\section{3 ) The security problem of M-commerce is urgently to be solved}

The feature that surfing the Internet is via the mobile terminals determines that the security problem of $\mathrm{M}$-commerce is more complicated and outstanding. Compared to the traditional M-commerce, the security of M-commerce is more fragile. However, the security problem is the base of Ebusiness and also it is the key factor whether M-commerce can be successful. The key link of M-commerce development is to assure the participants' security and prevent the users' legal information from violating. The development of Chinese Mcommerce is still in the early stage. There is no the national standard, industry standard or regulatory agency. Moreover, the market system is not normative. The operating environment of M-commerce has not been improved yet. All these factors have hindered the smooth development of $\mathrm{M}$ commerce. For the time being, the major security problems of M-commerce are mobile communication security, the operators' commercial platform security and the mobile terminals security etc [6]. The fact that how to protect the mobile electronic business participants' legal information (positioning, account, code, etc) from stealing, capturing and how to affirm the users' legal identity and how to prevent users' denying are all the problems which are to be solved urgently. In addition, the problem of safe electronic payment system, safe delivering system and other issues are to be solved urgently.

\section{The analysis of Chinese M-commerce development strategy}

\section{1 ) Strengthen the concept of M-commerce and cultivation and the cultivation of dealing custom}

M-commerce development in China is in the ascendant. It is in the stage of market cultivating now. The support from government is beneficial to the rapid and stable development of M-commerce. On the one hand, government should promote extensively via newspapers, broadcast, TV, Internet, etc. to make people have a full understanding of the M-commerce. On the other hand, government should adopt effective and pointed measures, such as lower taxes, increase allowance, increase interests etc. and to support actively the operators of M-commerce and construct the normative. Also, the government should carry out M-commerce demonstration project and promote the successful M-commerce ventures, guiding more ventures do the $\mathrm{M}$-commerce.

Meanwhile, M-commerce ventures should take various marketing measures and attract the consumers from various parts. Also, they should broaden service range, increase service mode, kind, and content to meet consumers `needs so as to attract more users and to strengthen people' M-commerce knowledge, set brand effect, expand market share and gradually strengthen the concept of $\mathrm{M}$-commerce and cultivation of dealing custom, developing M-commerce market.

\section{2) To establish and improve $M$-commerce legislation system as soon as possible}

As a new business model, M-commerce has just started in our country. There have not been corresponding national standards and unified management institutions in our country. At the same time, the system in our country is not standard and perfect enough, thus some economic disputes appear inevitably and legal issues of $\mathrm{M}$-commerce are highlighted. To establish and improve the M-commerce legislation system as soon as possible and to create a legal environment conducive to the development of $\mathrm{M}$-commerce is the premise and foundation for the steady development of M-commerce. Only by laws, M-commerce can develop healthily and orderly. Although our country has promulgated the electronic signature law of the People's Republic of China in 2005, and the people's bank of China has worked out the electronic payment guidelines 1, the two laws and regulations involves very little of M-commerce. Therefore we should develop the $\mathrm{M}$ commerce law as soon as possible and the measures for $\mathrm{M}$ commerce payment settlement and other supporting laws and regulations. To establish and improve the M-commerce legislation system as soon as possible is still imperative in the development of M-commerce.

Also we must be aware that the conditions for developing new mobile electronic commerce law in our country are not yet mature at present. The legislature should deeply study the rules and trend of global M-commerce development, fully absorbing the legislation experiences of developed countries and international organizations based on the reality of our country and current business legal system and the domestic development of M-commerce strategy and objectives, and make law step by step gradually [7]. We should focus on the legislation of mobile electronic payment and personal privacy protection in the early days, supplanting the suspicion of $\mathrm{M}$ commerce, protect the rights and interests of businesses and consumers fully and arouse the enthusiasm of people to carry out the mobile electronic commerce.

Finally, the law is a double-edged sword. So the legislation on $\mathrm{M}$-commerce can neither be too early nor too late. If the legislation is too early, it may restrict, limit, and even hinder the development of M-commerce; if the legislation is too late, it is likely to jeopardize the interests of the participants of e-business, which is not conducive to the development of M-commerce. So choosing the right timing is very crucial. Only by following the rules of the development of M-commerce, improving the M-commerce legislation system, we can ensure its health and rapid development.

\section{3 ) To build a safe and reliable M-commerce security system}

Mobile security technology protecting the M-commerce 
participants' trade secret and legal property plays a very important role in the M-commerce system.

M-commerce is the business activity based on the wireless network. In order to ensure the safety of $\mathrm{M}$ commerce, we must build safe and reliable mobile network platform at first and establish secure wireless data transmission channel, so as to establish safe and reliable wireless network environment effectively to realize mobile commerce information security transmission. Mobile terminal is essential hardware of M-commerce, but the probability of mobile terminal loss is high. Although some manufacturers have antitheft feature of mobile terminals, most of the mobile terminals are still not have this function. If we can completely solve the security of mobile terminals, M-commerce will be more rapidly enter our daily life; Mobile terminal operating system is the key factor for M-commerce security, loopholes of the operating system is the main way for illegal attack and virus invasion. Software service provider should continuous improve the mobile terminal operating system and ensure the availability, stability and reliability. In order to solve this problem very well, mobile terminal manufacturers, mobile software developers, mobile service providers, merchants and users should do the joint efforts. Finally, in order to ensure the normal order of the M-commerce operation, we must improve M-commerce participants' safety awareness, and strengthen the credit consciousness, risk consciousness and consciousness of security trading [6]. We must strengthen the M-commerce security management and establish mobile commerce security specifications, so as to create a healthy, sincere, safe and sound environment for M-commerce.

\section{4) To strengthen the cultivation of talents, and promote the research of M-commerce theory}

$\mathrm{M}$-commerce has begun to develop rapidly in China, but still in the early stage of development, and some of the service is still in the test or trial stage. M-commerce is "the new world" to a large extent and there are a lot of under-researched areas. Its development can't be smooth. So we need to strengthen the talents cultivation, and the senior specialized talents are strategic resources in the development of $\mathrm{M}$ - commerce. Government should actively learn and absorb foreign advanced experience, formulate relevant incentive policies, establish and improve the talents, the innovation of institutional environment, plan M-commerce specialized talent introduction and training, enhancing university-enterprise cooperation between research and development, vigorously support the development of relevant training institutions.

At the same time, we should carry out a comprehensive in-depth development of theoretical research in the field of Mcommerce, based on the present situation and trend of Mcommerce development at home and abroad. At present, with the continuous development of M-commerce at home and abroad, the M-commerce theory research mainly includes the study on the economics of M-commerce, M-commerce strategy research, M-commerce business model, M-commerce behavior study, all kinds of M-commerce security technology research, M-commerce application research and cross-cultural research [2]. Government should make a breakthrough in the field of institutional arrangements, incentive mechanism and policy inclination to encourage enterprises and research institutes, so as to guide the mobile electronic business go ahead smoothly in the correct direction, seize the historical opportunity, so as to achieve the leap development of Mcommerce in China.

\section{References}

[1] Chunyan Zhao, "The influence factors and the countermeasures of Mcommerce development in our country," Economic Tribune, July 2011, pp. 24-26.

[2] Qingyan Li, Duo Jin etc, "Discussion the trend of M-commerce development," Journal of telecom science, June 2011, pp.14-18.

[3] Chen Haiting, "Summarized research status quo and trend of development of China mobile e-busines," Journal of Silicon Valley, April 2010, pp. 47-52.

[4] Qin Zheng. Mobile e-business: Tsinghua University Press, 2012, pp.5662.

[5] Tingjie Lv, M-commerce: Electronic Industry Press, 2011, pp. 150-152.

[6] Xingli Yang, The theory and application of M-commerce: Beijing University of Posts and Telecommunications Press, 2010, pp. 201-220. 